Private Sector Agricultural Research: Research Priorities of Agribusiness and How They Are Changing Farmers' Lives

Hope Shand

\title{
OpenEdition
}

Journals

Electronic version

URL: http://journals.openedition.org/sjep/877

DOI: $10.4000 /$ sjep.877

ISSN: 1663-9677

Publisher

Institut de hautes études internationales et du développement

Printed version

Date of publication: 1 May 2002

Number of pages: $65-76$

ISSN: 1660-5926

Electronic reference

Hope Shand, «Private Sector Agricultural Research: Research Priorities of Agribusiness and How They Are Changing Farmers' Lives », Schweizerisches Jahrbuch für Entwicklungspolitik [Online], 21 | 2002,

Online since 10 September 2012, connection on 07 September 2020. URL : http://

journals.openedition.org/sjep/877 ; DOI : https://doi.org/10.4000/sjep.877 


\section{PRIVATE SECTOR AGRICULTURAL RESEARCH: RESEARCH PRIORITIES OF AGRIBUSINESS AND HOW THEY ARE CHANGING FARMERS' LIVES}

HOPE SHAND*

\section{INTRODUCTION}

Unfortunately, the crisis in agricultural research is little known or understood outside of a small circle of international development agencies, civil society organizations, and agricultural institutions. The fact that agricultural research is not headline news makes it an especially important topic for World Food Day. The crisis affects everyone - North and South, rich and poor - whether we realize it or not. Why does agricultural research matter? Why should we care that investment in public agricultural research is collapsing ? Why should we be concerned that private sector research is consolidating into the hands of a few, giant corporations?

Public Agricultural Research Is Collapsing : Both national governments and aid agencies are reducing their commitment to agricultural research and development, in both the North and the South. Public funds for agricultural research have stagnated or declined:

$\checkmark$ There is an almost universal trend toward slower growth in public expenditures for agricultural research. ${ }^{1}$ The rate of growth slowed from $4.6 \%$ in $1976-81$ to $1.7 \%$ in $1991-1996 .^{2}$ All regions of the developing world experienced slower growth rates.

a Annual foreign aid to agriculture in poor countries fell by $57 \%$ between 1988 and 1996 (from $\$ 9.24$ billion down to just $\$ 4.0$ billion, measured in constant 1990 dollars). ${ }^{3}$

- Annual World Bank lending for agriculture and rural development fell by $47 \%$ between 1986 and 1998 (from $\$ 6$ billion to just $\$ 3.2$ billion, measured in constant 1996 dollars). ${ }^{4}$

๑ Partly under pressure from donor and lending institutions, developing countries have also reduced public spending on agriculture. On average, developing

* Research Director, Action Group on Erosion, Technology and Concentration: ETC Group (formerly RAFI).

This article was prepared for a Conference sponsored by Bern Declaration and Swiss Aid, 12 October 2001, World Food Day («La recherche agricole: pour qui?», Tagung «Agrarforschung - für wen?»).

1. Derek Byerlee, Gary Alex, and Ruben G. Echeverría, "The Evolution of Public Research Systems in Developing Countries : Facing New Challenges," Agricultural Research Systems in an Era of Privatization, unpublished chapter for forthcoming book (2001).

2. Ibid.

3. Alston, J.-M., P.G. Pardey, and J. Roseboom, "Financing Agricultural Research: International Investment Patterns and Policy Perspectives," World Development, Vol. 26, No. 6, 1998, pp. 1057-1071.

4. Paarlberg, Robert, "The Global Food Fight," Foreign Affairs, May/June 2000, p. 36. 
countries devote only $7.5 \%$ of total government spending to agriculture, and little of this goes for research. ${ }^{5}$

- China and India have the largest agricultural research systems in the world, and together account for over one-half of the South's research capacity. ${ }^{6}$ Over two-thirds of the national agricultural research systems in developing countries employ fewer than 200 researchers.

- Sub-Saharan Africa has only 42 agricultural researchers per million economically active persons in agriculture, compared with an average of 2,458 researchers per million in OECD countries.?

The neglect of agricultural research is dangerous and incomprehensible because $75 \%$ of the world's poorest people live in rural areas of the world. ${ }^{8}$ According to the Food and Agriculture Organization of the United Nations (FAO), almost a quarter of the world's population is fed by farmers who depend on farm-saved seed (that is, poor and subsistence farmers who produce in marginal farming environments). With the decline of public sector research, who will address the needs of poor farmers, global food security and the environment?

The Agricultural Research Agenda is Dominated by Fewer and Fewer Corporations: In OECD countries, private sector investment in agricultural research grew $5.1 \%$ per annum between $1981-1993,{ }^{9}$ and it is increasingly concentrated in the hands of fewer and fewer corporations.

$\square$ In OECD countries, investment in private research has grown twice as rapidly as public research since 1981. Private agricultural research has exceeded public research in the US, the UK and the Netherlands. ${ }^{10}$

- Over the past 15 years private-sector R\&D in the South has grown more rapidly than public-sector research. ${ }^{11}$ The absolute amount of private research in developing countries is very small relative to the amounts in OECD countries and compared to the size of agricultural economies.

Private sector R\&D in plant breeding and agricultural biotechnology, in particular, has experienced rapid growth and consolidation in the hands of a few global firms. Today, commercial plant breeding and ag biotech are proprietary sciences, and virtually all knowledge associated with them has been privatized. With the advent of genetic engineering, corporate breeders are staking farreaching claims of ownership over a vast array of living organisms and biological processes. The power of exclusive monopoly patents is giving these companies the legal right to determine who gets access to proprietary science and at what price. Concentration in corporate power has serious implications for the future of agriculture and world food security.

5. Ibid.

6. Derek Byerlee, Gary Alex, and Ruben G. Echeverría, "The Evolution of Public Research Systems in Developing Countries: Facing New Challenges," Agricultural Research Systems in An Era of Privatization, unpublished chapter for forthcoming book (2001).

7. Paarlberg, Robert, "The Global Food Fight," Foreign Affairs, May/June 2000, p. 36.

8. For a fuller discussion, please see: RAFI, "In Search of Higher Ground," RAFI Occasional Paper, Vol. 6, No. 1, September, 2000, <www.etcgroup.org>.

9. Alston, J.-M., P.G. Pardey, and J. Roseboom, "Financing Agricultural Research: International Investment Patterns and Policy Perspectives," World Development, Vol. 26, No. 6, 1998, pp. 1057-1071.

10. Pray, Carl. "The Growing Role of the Private Sector in Agricultural Research," Agricultural Research Systems in an Era of Privatization, unpublished chapter for forthcoming book (2001).

11. Ibid. 
What are the private sector research priorities and how are they changing farmers' lives? Who are the major players? Why should we be concerned? This paper examines three major trends in private sector agricultural research, with a focus on plant breeding and biotechnology:

1. Corporate concentration

2. New Enclosures

3. Appropriation of Public Sector Research for Private Profit.

\section{CONCENTRATION IN CORPORATE POWER}

Perhaps the dominant trend in private sector agricultural research today is corporate concentration. Over the past few years we have witnessed a dramatic consolidation of power over agricultural resources worldwide, a trend that began over three decades ago. Giant, transnational enterprises are gaining unprecedented control over all aspects of commerce, food, farming and health. ${ }^{12}$ Consider the following examples:

」 20 years ago there were thousands of seed companies, most of which were small and family owned. Today, the top 10 global seed companies control almost one-third of the $\$ 24.4$ billion commercial seed trade. Transnational enterprises are now more aggressively acquiring seed companies in the South - particularly in major markets of Brazil, Argentina, China and India. ${ }^{13}$

๖ 20 years ago we were monitoring about 65 agrochemical companies involved in the development of new crop chemicals. Today the top 10 pesticide manufacturers account for $84 \%$ of the $\$ 30$ billion dollar global market.

๖ 20 years ago, the top 10 global pharmaceutical companies controlled roughly $20 \%$ of the global pharmaceutical trade. Today, the top 10 drug companies account for almost half of the $\$ 317$ billion global pharmaceutical market.

๖ Today, 10 firms control $60 \%$ of the animal veterinary market valued at (US) $\$ 16$ billion.

The dominant companies in all of these sectors - in plant breeding, pesticides, veterinary medicines and pharmaceuticals - are known as the "Gene Giants." They include the world's largest agrochemical and pharmaceutical corporations.

Today, access to new agricultural biotechnologies is legally restricted by a complex pedigree of patented genes, genetic traits, and enabling technologies. A study by Gregory Graff at the University of California at Berkeley illustrates the degree to which the Gene Giants control key ag biotech patents and technology. At the end of 1998 the US Patent and Trademark Office had granted 1,370 ag biotech patents to the top 30 patent assignees. Three-quarters (74\%) of the ag biotech patents (of those awarded to the top 30 assignees) were held by six

12. All of the following statistics on corporate concentration by sector are found in: ETC Group (formerly RAFI), ETC Group Communiqué, "Globalization, Inc.: Concentration in Corporate Power: The Unmentioned Agenda," July/August, 2001, <www.etcgroup.org>.

13. RAFI, "The Seed Giants: Who Owns Whom?," December 2000. On the Internet: <www.etcgroup. org $>$. 
Gene Giants: Pharmacia (Monsanto) (287 patents); DuPont (279 patents); Syngenta (173 patents); Dow (157 patents); Aventis (77 patents); and Grupo Pulsar (38 patents). ${ }^{14}$

Private Sector Agricultural R\&D

Sample of Major Players in Plant Breeding (in US\$ Millions)

\begin{tabular}{lcc}
\hline Company & 2000 Sales & $\begin{array}{c}\text { Agricultural R\&D } \\
\text { Budget 2000 }\end{array}$ \\
\hline Pharmacia (US), Monsanto only & 5,493 & 588 \\
\hline Syngenta (Switzerland) & 6,846 & 537 \\
\hline DuPont (US), Pioneer only & 1,900 & $\sim 190$ \\
& & (Pioneer only) \\
\hline Aventis Crop Science (for sale) & 3,731 & 409 \\
\hline Limagrin (France) & 622 & 71 \\
\hline Seminis (Mexico) & 474 & 58 \\
\hline BASF (Germany), ag products only & 2,246 & 253 \\
\hline Bayer (Germany), agriculture only & 3,196 & 341 \\
\hline DowAgroSciences (US) & 2,300 & $?$ \\
\hline
\end{tabular}

Source: ETC Group.

Note: for some of the companies listed above, the sales and R\&D figures include both agrochemicals and seeds. It is difficult to obtain figures on R\&D for plant breeding or plant genetics/biotech, separate from other agricultural products. By contrast, the public sector Consultative Group on International Agricultural Research spent \$338 million in 2000.

The Gene Giants' control of patented genes and traits has already created legal barriers which makes it difficult or impossible for small companies or public sector researchers to compete, or to gain access to new agricultural technologies. Will proprietary science be accessible or affordable to researchers, farmers and consumers in the South? In the words of Professor Gordon Conway, President of the Rockefeller Foundation:

"As plant research in the industrialized world has come to be dominated by private companies who closely guard their proprietary technologies, the process of innovation in the developing countries has slowed. Public sector plant breeders don't know how to respond, and when they try, they are handicapped by the huge disparity in resources and negotiating power between themselves and the companies."15

\section{WHAT IS THE PRIVATE SECTOR'S RESEARCH ORIENTATION?}

It is important to stress that private and public researchers perform markedly different duties. Food processing and post-harvest research dominates private research, accounting for $30-90 \%$ of all private agricultural R\&D. ${ }^{16}$ Only $12 \%$ of corporate research focuses on farm-level technologies. In contrast, $80 \%$ of public research is oriented (at least theoretically) to the farmer. Relatively little pri-

14.ETC Group analysis of patents, 9 February 2001. The original patent breakdown by company for top 30 patent assignees is presented in Gregory Graff, dissertation, Department of Agricultural \& Resource Economics, U.C. Berkeley, forthcoming, 2001, <http://are.berkeley.edu/ ggraft/IPCMbackground.html>.

15. Speech by Gordon Conway entitled "The Rockefeller Foundation and Plant Biotechnology." The speech was made to the Monsanto board of directors on 24 June 1999 in Washington, D.C.

16. Alston, J.-M., P.G. Pardey, and J. Roseboom, "Financing Agricultural Research: International Investment Patterns and Policy Perspectives," World Development, Vol. 26, No. 6, 1998, pp. 1057-1071. 
vate agricultural research takes place in the South. The private sector share of total agricultural research expenditures is estimated at only $5 \%$ in developing countries. In the developing world, transnational firms concentrate R\&D in the biggest markets (such as Brazil, Argentina, India, and China), and on industrial crop commodities produced by large-scale farmers. ${ }^{17}$

We can learn a great deal about the private sector's agricultural research agenda by looking at the commercial introduction of genetically modified (GM) crops over the past five years. The statistics show an extraordinarily rapid market introduction, dominated almost exclusively by a single company, in limited geographical areas. Commercial GM crops can be summarized by the following four points:

- Four major industrial crop commodities. Soybean, maize, cotton and canola account for virtually all commercial GM crops planted in $2000 .{ }^{18}$ These industrial crop commodities are not grown by poor and subsistence farmers.

- Three countries. Last year, $98 \%$ of all GM crops were grown in the US, Argentina, and Canada.

- Two genetic traits. Three-quarters of the area devoted to GM crops last year were engineered for a single trait - herbicide tolerance; the rest was modified for insect resistance based on Bacillus thuringiensis (a very small percentage of GM crops were engineered for both traits).

- One company. Monsanto's (now Pharmacia) GM seed technology accounted for $94 \%$ of the total area sown to GM crops last year. ${ }^{19}$

Uniformity, industrial agriculture and corporate concentration are words that would best describe the introduction of GM crops over the past five years - not diversity, food security, sustainability or competitive markets.

By and large, corporate breeders are interested in temperate zones, not tropical; they focus on industrial crop commodities, not subsistence agriculture. Corporate breeders are developing products that reinforce farmers' dependence on purchased inputs, not self-reliance in food production. Private sector R\&D priorities generally do not focus on environmental suitability of crops, durable disease resistance or nutritional characteristics. Putting aside the many unresolved and controversial questions relating to the safety and ecological impacts of GM crops - it is clear that commercial GM products at this point in time are neither accessible, affordable nor relevant for poor farmers and poor consumers in the South.

17. Pray, Carl, "The Growing Role of the Private Sector in Agricultural Research," Agricultural Research Systems in an Era of Privatization, unpublished chapter for forthcoming book (2001).

18. International Service for the Acquisition of Agri-biotech Applications, ISAAA.

19. Monsanto, "Monsanto Reports Pro Forma Fourth-Quarter 2000 Earnings," 12 February 2001, $<w w w . m o n s a n t o . c o m>$. Monsanto claims that its biotech traits were planted on 103 million acres in 2000. This is equivalent to $94 \%$ of the total worldwide area sown to commercial GM seeds in 2000 , according to ISAAA (109.2 million acres or 44.2 million hectares). 
The most alarming trend in agriculture today is that farmers, indigenous peoples and public sector researchers are losing the right to use and develop diversity. Both private and public sector institutions are developing and promoting a variety of legal and technological tools that are designed to eliminate the right of farmers to save and exchange seed, and breed their own crops. The farmers' right to use and develop diversity is being eroded by intellectual property monopolies and new technologies.

It is important to point out that the people who work in the corporate offices of Syngenta, or Monsanto or DuPont would not agree with this analysis. They do not see themselves as taking away the rights of farmers. They see this issue from a very different perspective. They would explain that the private sector is merely appropriating sufficient returns to encourage its investment in agricultural research. "Appropriability" is an important precondition for profit and participation of the private sector in ag research. Using exclusionary mechanisms (legal tools such as intellectual property monopolies, or biological tools such as genetic seed sterilization), they have transformed research output from a "public good" to a "proprietary" good.

Why does this matter? Farmers have been selecting seeds and adapting their plants for local use for over 200 generations. Up to 1.4 billion people in the South depend on farm-saved seeds as their primary seed source. Crop genetic diversity is the basis for local food security. It enables farmers to adapt crops suited to their own ecological needs and cultural traditions. Communities that lose control over their seeds, adapted over centuries to their needs, risk losing control of their farming systems and becoming dependent on outside sources of seeds and the inputs they require. Without an agricultural system adapted to a community and its environment, self-reliance in agriculture is impossible.

When genetic engineers at Monsanto or Syngenta develop a new variety of soya, cotton or maize they are building on the accumulated success of generations of farmers, who have selected and improved seeds for thousands of years. These companies insist that they "invented" their genetically engineered plants and that they should be rewarded with exclusive monopoly patents. In reality, corporate plant breeders are fine-tuning and modifying plants that were developed by anonymous farmers and the more recent contributions of institutional plant breeders.

Today, under US patent law, it is illegal for farmers to save patented seed and re-use it. In the United States, firms like Monsanto and DuPont require farmers to sign gene licensing agreements before they buy the company's patented, genetically engineered seeds. When farmers are caught infringing the patent, Monsanto is "vigorously prosecuting" them in court. In some areas, the company has hired Pinkerton investigators to root-out farmers who are saving Monsanto's patented seed. Although the high-profile case of Canadian farmer Percy Schmeiser has received widespread coverage in the media - it is just the tip of the iceberg. As of mid-2001, Monsanto has filed more than 475 lawsuits against farmers for patent infringement and violation of technology user agreements. ${ }^{20}$

20. The statistic is cited in Amici Curiae brief prepared by Joseph Mendelson and Andrew C. Kimbrell. J.E.M. AgSupply, Inc. v. Pioneer Hi-Bred International, Inc., No. 99-1996. 
In essence, farmers are being turned into criminals and rural communities are becoming corporate police states. Some people may think that the experience of North American farmers is largely irrelevant for farmers in the South. But last year, The National Seed Institute (INASE) of Argentina proposed using satellite surveillance to stop illegal seed commerce among Argentine farmers. ${ }^{21}$ India's new Plant Variety Protection bill includes penalties for farmers who re-sell corporate seeds. $^{22}$

\section{NEW ENCLOSURES: TERMINATOR AND TRAITOR TECHNOLOGY}

Of course, it is expensive and politically unpopular for companies like Monsanto to enforce their patents - and it's bad public relations to sue farmers. That is one of the reasons why the Gene Giants are developing a variety of new mechanisms to enforce corporate monopoly. This is what the ETC Group refers to as "New Enclosures." 23 As patents become politically unpredictable and practically unreliable, corporations are developing non-patent mechanisms to secure monopoly control of new technologies.

The most obvious example of a "New Enclosure" mechanism is Terminator technology - plants that are genetically engineered to render sterile seeds. Though not yet commercialized, the primary aim of genetic seed sterilization is to maximize seed industry profits by destroying the ability of farmers to save their seeds and breed their own crops. The technology prevents farmers from saving seed from their harvest, forcing them to return to the commercial seed market every year. Genetic seed sterilization goes beyond intellectual property as an appropriation mechanism for the Gene Giants, because unlike patents or plant breeders' rights, Terminator technology is not time limited and there are no exemptions. A typical patent provides an exclusive legal monopoly for 20 years - but Terminator is a monopoly with no expiration date. It is the perfect tool for the corporate seed industry in a global market - because it destroys the concept of national food sovereignty.

The U.S. Department of Agriculture and Delta \& Pine Land, the world's largest cotton seed company, jointly own three patents on genetic seed sterilization. In 1998, the president of Delta \& Pine Land told a US seed trade journal that his company's seed sterilizing technology could be used on over 405 million hectares worldwide (an area the size of South Asia), and that it could generate revenues for his company in excess of $\$ 1$ billion per annum. ${ }^{24}$

21. "Tecnología satelital para detectar comercio illegal," Revista Chacra, on the Internet: <www. revistachacra.com.ar/notas/cne200006n06.htm>.

22. Centre for Science and Environment, "Seeds of Discontent? - and - Who is Protected?" Down to Earth, Vol. 10, No. 8, p. 6 and pp. 48-5115 September 2001. In August 2001 India's lower house of parliament, the Lok Sabha, approved the "Protection of Plant Varieties and Farmers' Rights Bill of 1999." The bill must be passed by the upper house before it becomes law.

23. Please see ETC Group's Communiqué: "New Enclosures: Alternative Mechanisms to Enhance Corporate Monopoly and BioSerfdom in the 21st Century," November/December, 2001, $<w w w . e t c g r o u p . o r g>$.

24. Freiberg, B., "Is Delta \& Pine Land's Terminator Gene a Billion Dollar Discovery?" Seeds and Crop Digest, March/April, 1998. 
In 1999, both Monsanto and AstraZeneca made a public commitment not to commercialize Terminator seeds. As a result, many people were led to believe that the crisis has passed. Unfortunately, this is not the case. Both Monsanto and AstraZeneca have merged with other companies since they made their announcements. Monsanto is now owned by Pharmacia and AstraZeneca has merged its agribusiness with Novartis to become Syngenta. The most recent Terminator patent (that we know about) was granted to Syngenta in November 2000.

In August 2001 the US Department of Agriculture announced that it had concluded negotiations to license its Terminator patent to Delta \& Pine Land. ${ }^{25}$ In effect, the US government has officially sanctioned commercialization of the technology by licensing it to one of the world's largest seed companies. Delta \& Pine Land has publicly announced its intention to commercialize Terminator seeds. ${ }^{26}$

Although Terminator has grabbed the spotlight, genetic trait control technology - or GURTs (genetic use restriction technology) - is potentially more far-reaching and dangerous. With genetic trait control the goal is to turn a plant's genetic traits "on" or "off" with the application of an external chemical. If companies can successfully engineer seeds to perform only with the application of a proprietary pesticide or fertilizer, for example, it will reinforce chemical dependencies in agriculture - and both farmers and food security will be held hostage to the Gene Giants.

Especially alarming are patents describing plants that have weakened immune systems. In most cases, the inventors claim that they are developing "immune compromised" plants for research purposes, to test the efficacy of fungicides, to examine plant-pathogen interactions, or to enhance disease resistance, for example. But some of the patents suggest otherwise. The patents also describe the development of plants whose natural immune system is disabled, and would therefore be highly vulnerable to pests and disease - unless chemicals are used to restore the plant's missing immunities. Would agrochemical companies intentionally create weakened plant strains? They already have. Would they attempt to commercialize "disease susceptible plants" that would require chemical spraying to restore missing immunities? There is nothing to stop them.

Unless governments take action to ban these technologies, they will be commercialized, with devastating consequences for farmers, food security and biodiversity.

\section{PUBLIC RESEARCH FOR PRIVATE PROFIT: NEW ALLIANCES AND PARTNERSHIPS THREATEN TO DISTORT THE PUBLIC RESEARCH AGENDA}

A rapidly changing intellectual property environment coupled with stagnant budgets for public research has effectively marginalized the role of public sector agricultural research in both OECD countries and the South. Public organizations everywhere are under pressure to act more like private firms: to patent their research, commercialize their products and earn income to offset declines in pub-

25. RAFI, News Release, "USDA Says Yes to Terminator," 3 August 2001, <www.etcgroup.org>.

26. Personal communication with Harry Collins, spokesman for Delta \& Pine Land, 7 February 2001. 
lic funding. As a result, a variety of new partnerships and alliances are emerging between the public and private sectors. The consolidated power of corporate $\mathrm{R} \& \mathrm{D}$ is already influencing and distorting the public sector research agenda. We are concerned about the neglect of the public good, and the appropriation of public research for private profit. Public sector researchers and their institutions are in danger of becoming little more than contract workers or offshore laboratories for multinational corporations. Consider the following examples:

Golden Rice: With the global backlash against GM foods, the biotech industry is desperate to establish moral legitimacy for GM products. ${ }^{27}$ As a result, we have been bombarded with news about the development of "Golden Rice" - a genetically modified rice with high levels of beta carotene designed to combat the severe nutritional problem of Vitamin A deficiency in the South. Despite the fact that Golden Rice research was funded entirely by the public sector, it has been appropriated as a public relations tool for the biotech industry. It has yet to be determined whether or not Golden Rice is a safe or appropriate technology. ETC Group's research has focused on the intellectual property aspects of Golden Rice. After a decade of publicly funded research, Golden Rice researchers found that they ran the risk of infringing some 70 patents held by as many as 32 companies and institutions. Faced with the high costs and legal complexities of negotiating patent licenses, the Golden Rice researchers struck a deal with agrochemical giant, AstraZeneca (now Syngenta). In May 2000, AstraZeneca announced that it was taking over the further development of vitamin-A rice. In exchange for exclusive commercial rights to Golden Rice in the North (and among medium and larger-scale farmers in the South), AstraZeneca promised to make the technology freely available to poor farmers in developing countries, and to give regulatory, advisory and research assistance in making it available to developing countries.

Last year, ETC Group examined the 70 patents related to Golden Rice, ${ }^{28}$ and we looked at the 60 countries that suffer the highest levels of Vitamin A deficiency. In reality, only a very small percentage of the patents are relevant for the poor countries suffering the most from vitamin-A deficiency. Only a few patents held by the private sector actually conflict with the further development of Golden Rice for the South. Of the four companies with patents, two - Monsanto (now Pharmacia) and AstraZeneca (now Syngenta) - have already agreed to royalty free licensing, leaving only two other major players, Aventis and DuPont, to agree to the same. At most, 11 patents are considered a constraint in the project's development - but over half of the countries we looked at do not recognize any of the patents. These countries have every legal right to utilize any technology not patented within their territories.

Ultimately, AstraZeneca (now Syngenta) captured years of public investment at minimum cost - a "public good" was surrendered to a private company. The Golden Rice deal is a case study in the public sector's mismanagement of intellectual property. This case illustrates a dangerous scenario for the future of

27. For more information, see: RAFI, "Biotech's Generation 3," RAFI Communiqué, Issue No. 67, November/December 2000. Available on the Internet : <www.etcgroup.org >.

28. RAFI, "Golden Rice and Trojan Trade Reps: A Case Study in the Public Sector's Mismanagement of Intellectual Property," RAFI Communiqué, September/October 2000, Issue No. 66. Available on the Internet: <www.etcgroup.org>. 
technology transfer: increasingly, the terms and conditions for technology transfer are being dictated by the Gene Giants based on the sanctity of exclusive monopoly patents - instead of the needs of the South's poor.

CGIAR and IP: The Consultative Group on International Agricultural Research (CGIAR) is an informal network of 16 international agricultural research centres that manages approximately 600,000 agricultural seed samples (the vast majority of which originated in the South's farming communities). The CGIAR's network is the most influential agricultural research body in the South, and thus affects food and agricultural development policies for resourcepoor farmers worldwide. In 1994, most of the crop germplasm held in CGIAR gene banks was placed under the auspices of the FAO, to be held in trust for the world community, and off-limits to intellectual property claims. While acknowledging the important role that CGIAR plays in agricultural research in the South, the ETC Group and many other CSOs have been critical of CGIAR policies related to science, governance and intellectual property.

We find it particularly alarming that some of the CGIAR's publicly-funded centres are now pursuing, rather than rejecting, intellectual property. ${ }^{29}$ The CGIAR argues that they must patent as a "defensive" measure to keep important innovations from being claimed by corporate science. Regardless of the motivation, we believe that pro-patent policies will distort the CGIAR's mission to serve poor farmers, take scarce resources away from agricultural research, and compromise its commitment to insure that crop germplasm remains accessible to the world community without restriction. Rather than pursuing the IP path, public research institutes need to examine policy alternatives that will keep public science in the public domain. Last year ETC Group published a paper, In Search of Higher Ground, that offers 28 specific policy initiatives. ${ }^{30}$

\section{Six Laws for Farmer-Led Food Security}

1. There is no food security without secure farm communities. Therefore the Right to Food includes the Rights of Indigenous Peoples and Farmers' Rights.

2. The more farm communities, the greater our collective farm security.

3. Food security requires diversity - of cultures, of germplasm and species, of technologies, and of distribution systems.

4. Sustainable food security cannot be dependent upon external inputs - material or intellectual.

5. Farmers have the right to access the best possible materials and technologies and to choose to work with other researchers, as they deem appropriate.

6. Holistic approaches to food security within the farming community must be reciprocated by holistic national and international support strategies.

Source: RAFI Communiqué, "In Search of Common Ground II," Issue No. 70, May/June 2001, <www.etcgroup.org>.

29. Dalton, Rex, "Cereal Gene Bank Accepts Need for Patents," Nature No. 404, p. 534, April 2000.

30. RAFI, "In Search of Higher Ground," RAFI Occasional Paper, Vol. 6, No. 1, September 2000. $<w w w . e t c g r o u p . o r g>$. 


\section{CONCLUSION}

There is a glaring contradiction between the world's agricultural research agenda and the research needs of the world's resource-poor farmers. Neglect of the public good is inevitable when the research agenda is based on pursuit of corporate profits instead of meeting human needs. Fortunately, there is increasing public awareness about the inequities and controversies surrounding control and ownership of genetic resources, and growing consensus that intellectual property requires urgent societal review. Too many patents are being granted for too long, and the subject matter being monopolized is too often someone else's innovation and knowledge. Instead of promoting innovation, patents are stifling innovation and hindering competition. The concerns are not just technical flaws, but the morality of a legal system that is fundamentally inequitable. Twentyyear monopolies granted by state authorities in record numbers are jeopardizing basic human rights, threatening food security and marginalizing public sector research.

There is an urgent and obvious need to increase public expenditures for agricultural research, but salvaging public science is not the simple solution. Renewed commitment to public sector agricultural research must be accompanied by reforms in governance and reorientation of research systems and science to support farmer-led food security. As one contribution to the ongoing debate, the ETC Group and the German NGO Forum Environment \& Development offer specific recommendations for reforming governance and science of the CGIAR system. ${ }^{31}$

From ETC Group's perspective, additional policy recommendations related to agricultural research include:

- WTO/TRIPs : Concerned governments should take action to rescind the current requirement, under Article 27.3b of WTO/TRIPs to implement intellectual property protection for plants and microorganisms, on the grounds that patenting regimes are fundamentally inequitable and predatory on the rights and knowledge of farming communities and indigenous peoples.

- Implementing Farmers' Rights: Both national and international action is needed to protect the inalienable right of farming communities to save, exchange and develop plant varieties without restriction. The International Treaty on Plant Genetic Resources for Food and Agriculture, adopted in November 2001, encourages governments to recognize Farmers' Rights. But the international dimension of Farmers' Rights was derailed by Article 9.3 of the Treaty, which makes implementation of Farmers' Rights subject to national law. Governments much discuss Farmers' Rights in the context of Food Sovereignty at the June 2002 World Food Summit, and press for implementation of Farmers' Rights through the UN Human Rights Commission's review of the Right to Food in mid-2002. ${ }^{32}$

31. See, RAFI Communiqué, "In Search of Common Ground II," Issue No. 70, May/June 2001, $<w w w . e t c g r o u p . o r g>$.

32. A detailed analysis of the International Treaty on Plant Genetic Resources, "The Law of the Seed," is available on the Internet: <www.etcgroup.org > 
- Terminating Terminator: Terminator technology has been universally condemned as the most morally offensive application of ag biotechnology. Governments will have important opportunities to ban Terminator technology; at the Biodiversity Convention's 6th Conference of Parties in April 2002; at the World Food Summit Five Years later in June 2002; and at UNCED's Rio+10 in South Africa, September 2002.

- Addressing Concentration: It is not possible to address world food security without addressing the impact of corporate hegemony. The United Nations system lost its capacity to monitor multinational corporations 10 years ago with the demise of the UN Centre on Transnational Corporations. The General Assembly should establish a new "UN Centre on Commerce and Technology," with a wider mandate and the necessary resources to address not only corporate power and concentration, but new commercial and technological combinations. Because of the vulnerability of the public sector, there is also a need to establish a code of conduct on agricultural research alliances between the public and private sector, to insure minimum levels of transparency and disclosure, and to protect the integrity of public science. 